\title{
CHEMISTRY IN THE SERVICE OF MEDICINE
}

$\mathrm{T}$ HE second British Congress on the History of Medicine and Pharmacy, organized by the Faculty of History of the Worshipful Society of Apothecaries of London in co-operation with the Chemical Society and sponsored by Glaxo Laboratories, Ltd., was held in London during September 27-29.

Prof. D. McKie, who occupies the chair of the history and philosophy of science at University College, London, was president of the congress, which had as its theme "Chemistry in the Service of Medicine". The twelve papers given provided an authoritative historical review of the services which chemistry has rendered to the development of medicine from the sixteenth century to the present day.

The inaugural session was held at Apothecaries' Hall on September 28, when Dr. A. G. Debus (Harvard University and University of Chicago) opened the proceedings with an account of Paracelsian doctrine in English medicine up to 1660. Prior to that date chemical methods and terminology were widely used in England on practical and theoretical levels. Chemical remedies and analysis did not originate with Paracelsus but were closely associated with the work of the iatrochemists. The impact of chemistry can be discerned in Paracelsian views on the origin of matter and in premature attempts to explain life processes in chemical terms. Theory was less popular in England than practice, but the present close bond between chemistry and medicine can be traced to the Paracelsian and Helmontian iatrochemists of the sixteenth and seventeenth centuries.

Dr. F. W. Gibbs (Royal Institute of Chemistry) emphasized the importance of Herman Boerhaave (1668-1738), who impressed a new, scientific, pattern on medical theory and practice in which chemistry had a central position. His Elementae Chemiae (1732) is a classic, the first volume being largely physical in outlook while the second is devoted to physiological, biochemical and clinical applications. The characteristics of his method were described with the aid of examples taken from his work on heat, pretended alkaline cures for gout and the stone, fermentation processes, and body fluids.

Prof. D. McKie spoke on "Chemistry in the Service of Medicine, 1600-1800" and described some of the many text-books of medical chemistry which appeared. in that period. Notable among these was the Cours de Chymie of Nicholas Lemery, which appeared in many editions between 1657 and 1757. Boerhaave's work had transformed chemistry into an academic science per se and rid it of its pharmaceutical bias. The next line of progress was exemplified by Van Helmont's work on 'gas', the experiments of Boyle on combustion and respiration, and the remarkable theories of Hooke and Mayow, the influence of which was deferred by the rise of the phlogiston theory. With Black's discovery of 'fixed air' as an 'air' chemically distinet from common air, and with similar studies by Cavendish, Priestley and Scheele, this problem approached solution with the work of Lavoisier, whose discovery of the compositions of air and water, together with his calorimetric studies on respiration, opened the way to physiology.

The afternoon session at the Royal College of Physicians, with Dr. Charles Newman in the chair, was opened by Prof. F. G. Young (Department of Biochemistry, University of Cambridge), who traced the rise of biochemistry between 1800 and 1900 . The idea that the chemical processes in living materials were subject to laws different from those applicable to the inorganic world lingered until almost mid-century. By the time it was largely rejected, the term 'organic chemistry' began to lose its original connotations and to be applied to synthetic compounds of carbons whether or not such substances had originally been derived from living matter. The controversies about fermentation and decomposition between Liebig and others, who included Schwann and Pasteur, were gradually decided in terms of the existence of intracellular enzymes. Ehrlich's early investigation on intracellular utilization of oxygen emphasized the role of activation of oxygen in the tissues for purposes of cellular combustion. The reasons why British chemists so largely ignored the possibility of applying their science to biology in general, and to animal metabolism in particular, are obscure, but may be found in the love of household pets (with dislike of animal experiments), the dominance of mathematical studies in British scientific education, and the controversies which followed the publication of The Origin of Species.

Speaking on the early history of pharmacology, Prof. W. D. M. Paton (Department of Pharmacology, University of Oxford) began by comparing the knowledge of drugs at the beginning of the nineteenth century, as shown in J. A. Paris's Pharmacologia, with that in Binz's Lectures in Pharmacology at the end. The main difference lay only in the general scientific background; although some important new drugs had been found in the intervening period the real revolution in therapeutics had scarcely begun. There was some exemplary work on the analysis of drug action and in structure/action relationships, but there was no consistent impetus or drive. When, therefore, did experimental pharmacology really get under way and what period could be defined as its 'early history'? Prof. Paton sought to answer this by studying the rate of change in the pharmacopoias, by tracing the rise and fall of different types of preparation and the introduction of substances pure enough to inject, by following the development of new 'unnatural' chemical structures, and by charting the rate of establishment of fully fledged departments of experimental pharmacology. All this type of evidence indicated that pharmacology was only now reaching maturity and that the main contribution which it would make to medicine, as well as to general biological science, was still to come.

Dr. W. D. Foster, of Dudley Road Hospital, Birmingham, and formerly of St. Thomas's Hospital, London, spoke on chemical pathology, which began as an extension of two ancient diagnostic procedures: uroscopy and the inspection of blood shed at therapeutic phlebotomy. Between about 1680 and 1740 , men such as T. Willis, J. Locke, R. Boyle and B. Langrish conceived that useful diagnostic information might be obtained by chemical analysis as well as inspection of blood and urine, but because of the limitations of chemistry obtained no useful results. A simpler approach to blood analysis in which the weight of fibrin, red cell mass, serum protein and water 
was determined, enabled Andral, in the 1840 's, to establish that disease might produce chemical changes in the blood. The first really useful diagnostic test in chemical pathology was for the detection of albuminuria and was introduced largely through the work of three British physicians, W. C. Wells, J. Blackall and $R$. Bright, in the early nineteenth century.

The modern development of chemical pathology began during the first decade of the twentieth century, and depended on the introduction of venepuncture to obtain adequate blood samples and the development of colorimetric analysis which was both sufficiently sensitive and simple enough for clinical purposes.

At the third session, held at the Royal College of Surgeons on Friday morning, the help given by chemistry to the elucidation of certain important medical problems was discussed. Sir Charles Dodds traced the growth of endocrinology and of organic chemistry, the former from Addison's great work on the suprarenal capsules (1855) and Claude Bernard's work on glycogen, followed by Oliver and Schafer's experiments with an extract of the suprarenals in 1895, the latter beginning with Wöhler in 1828 and taking a great leap forward to synthetic organic chemistry with the contributions of Kekulé, Cooper, Van't Hoff and Le Bel. The synthesis of adrenaline was the first milestone, the second was the synthesis of thyroxine by Barger and Harington (1926), following its isolation by Kendall (1916) and the clinical work on myxœedema by Murray in 1891. In a remarkable diagram Prof. Dodds showed all the chemical activity which has stemmed from Addison's paper in 1855. Among the substances isolated and characterized from the suprarenals, and yet others derived from these substances, are ascorbic acid, adrenaline and the sympathome drugs (for example, amphetamine), cestradiol and its analogue stilbœstrol, cortisol and the derivatives triamcinolone and prednisolone, aldosterone and its derivatives, progesterone and analogous compounds, testosterone and the anabolic steroids, and, finally, noradrenaline and the whole group of antihistaminic drugs which stem from it. The stimulus for it all came from medicine and biology, and particularly from endocrinology.

Chemistry and cancer was the theme of the paper by Prof. Alexander Haddow, who discussed the role of chemical substances in cancer pathology and therapeutics. In 1775 Percival Pott had written a classic account of cancer of the scrotum in chimney. sweeps which definitely incriminated soot as the causative agent. During the industrial revolution, coal-tar, mineral-oil and pitch were added to soot as materials capable of causing a great deal of industrial and environmental cancer, as exemplified in Joseph Bell's description of skin cancer among workers in the Scottish shale-oil industry. The term 'carcinogen' was first used in 1853 by Sir James Paget, who cited Lebert (1851) as proposing that a chemist must aid the pathologist in research on cancer. After many attempts, experimental cancer was produced artificially by coal-tar by Yagamura (1915) and during 192126 Block showed that cyclic hydrocarbon was the active carcinogen. At about the same time the work of Cook and Kennaway vindicated Lebert's forecast and provided, using artificial tars, virtual proof of the carcinogen hypothesis, which was further extended by the implication of $3: 4$ benzpyrene, certain biological alkylating agents and other substances. It was stressed that there was no antithesis between the study of viruses and chemical carcinogens, for chemistry was essential to both. Chemotherapy, which had begun with Lissauer and the use of arsenic in the treatment of leukæmia, was already developing rapidly, as shown by the use of stilbœstrol in breast cancer and of other useful products such as myleran.

Dr. T. F. Macrae, speaking on ehemistry and nutrition, said that in the development of improved nutritional standards, especially in the past thirty years, chemistry has played a major part. Increases in crop yields have largely been due to synthetic fertilizers, adequate supplies of which have been ensured by the early discovery of nitrogen fixation. More recently further advances have accrued from the wide range of pesticides now available.

In the field of nutritional deficiencies the work of chemists on vitamins has been particularly beneficial. All the important vitamins are now available synthetically at costs far lower than from natural sources. Indeed, in advanced countries at least, vitamin deficiencies are no longer encountered. Similar developments are likely with the amino-acids, it now being a simple matter analytically to determine the adequacy or otherwise of a protein source. Already in animal nutrition it has in some instances proved more economic to provide part of the nutritional requirements in synthetic form.

There still remains, however, the problem of insdequate nutrition, especially of protein, in the under-developed countries. This is in part technological since, though we can identify the deficiency and, in chemical terms, propose the remedy, we still have to find sufficiently cheap means of providing this remedy in a form acceptable to the populations concerned.

In the final session, held at the Chemical Society's rooms with Sir Robert Robinson in the chair, Prof. D. Catcheside reviewed the relationship between chemistry and genetics, beginning with the rediscovery of Mendel's work in 1900 and the speculation about the nature of his 'elements'. Chemical knowledge of their action is more advanced than that of the genes themselves. It began with the study of the differences between phenotypes determined by single Mendelian differences, such as the flower pigments of snapdragons by Muriel Wheldale (Onslow). This showed that a gene controlled the onset of a specific chemical reaction. But the conception of a gene-enzymechemical reaction system was due to Garrod's work on alcaptonuria and other inborn errors of metabolism in man. $\mathrm{He}$ considered that the abnormal gene resulted in absence or inactivity of the enzyme that normally cleaves homogentisic acid, in turn giving rise to disordered metabolism and disease. The theory was revived by Beadle and Tatum, following work on the eye pigments of Drosophila, when they reversed the procedure by searching in Neurospora for gene mutations that influence known chemical reactions. This has led, with the aid of the analytical techniques of Pauling, Sanger and Ingram, to the demonstration of specific amino-acid substitutions in abnormal hæmoglobins, and, with the development of microbial genetics, to attempts to correlate genetical and chemical detail for several proteins in fungi, bacteria and bacteriophage. As regards the genes themselves, geneticists in the first place showed that they were in the chromosomes, but direct implication of deoxyribonucleic acid, knowledge of the chemistry of which is a recent event due to Wilkins, Watson and Crick, resulted from microbial genetics. First, the demonstration that deoxyribonucleic acid is the sole substance concerned in transformation of Pneumo. 
coccus (Avery et al.), and then that it is the vehicle of heredity in bacteriophage (Hershey et al.). More recently, attention has been directed to the coding problem and to the mechanism of transfer of specific information from deoxyribonucleic acid to protein.

A survey of progress "from antisepsis to antibiotics" was offered by Dr. W. A. R. Thomson, who said that although antisepties had a long history, the antiseptic principle was first established by Lister in 1867, an event which led to a long and successful search for bactericidal drugs. Landmarks in that search were Ehrlich's ' 606 ', demonstrating the possibility of treatment by specific drugs, the introduction of the sulphonamides and, third, of the antibiotics. The usefulness of the sulphonamides had not yet been fully exploited and 'the antibiotic rush' of the fifties may in retrospect be seen as fundamentally unscientific. The isolation of 6 -aminopenicillanic acid in 1959 marked the opening of a new and genuinely scientific era in antibiotic research. Dr. Thomson concluded with a word of caution; indiscriminate use of antibiotics had upset the balance of Nature and "the mass-murder of micro-organisms" was not necessarily a good thing. The careful use of antibiotics combined with immunotherapy offered a wiser course for the future.

Dr. F. L. Rose took one of the important developments of the same period for closer investigation in his account of the origin and rise of the synthetic drugs. With one or two exceptions, he said, all the medicaments available until the mid-nineteenth century were natural products. At that point in time, the coincidental discovery of the first synthetic dyestuffs and of micro-organismal origin of infectious diseases soon brought about a rapid change. The former because it caused an almost explosive growth of synthetic organic chemistry in a way which invited its direction into biological pathways, and the latter because it provided the motive and means for examining the effect on disease of the compounds poured out by the chemists. Thus the evolution of the modern antimalarial agents can be traced back directly to the observed staining of the malaria parasite by methylene blue. Methylene blue is a derivative of phenothiazine, itself widely used as an anthelmintic, and from which stem some of the most effective tranquillizing agents. Similarly, the modern trypanocides owe their beginning to the feeble therapeutic action shown by the early direct cotton dyestuffs, and the medicinal properties, initially antiseptic but later trypanocidal, found in the first azine and cyanine dyestuffs. Likewise, the appear. ance of the first azosulphonamide drug coincided with interest in the use of the sulphonamide group as a component of azo dyestuffs. These drugs were additionally important in that their technical develop. ment directed attention to the sulphones, now widely used in leprosy, while minor side effects were ex. ploited to produce highly effective diuretic and hyperglycæmic agents.

A dinner was held in Apothecaries' Hall when the guest of honour was Sir Howard Florey, and the president of the Chemical Society, Sir Alexander Todd, gave the after-dinner address. He discussed the long-standing relationship between chemistry and medicine and stressed that the indebtedness was mutual, for medicine and its neods had provided a very great impetus to the growth of chemical research. He found in the title of the congress a reflexion of the orthodox separation of the basic sciences, a situation which was probably incapable of fruitful development. Many important problems required workers with many kinds of scientific skill, and although research institutes may provide this kind of team, research was still best undertaken by the universities. The barriers between departments must be broken down to enable the constant influx of young rainds to cross the barriers between the sciences.

The papers given at the congress are to be published in volume form. It has already been decided that the meeting next year will be held in London during September $27-28$, and will have as its theme "The History of British Hospitels". F. N. L. POYNTER

\section{THE AUSTRALIAN NATIONAL RADIO ASTRONOMY OBSERVATORY}

\begin{abstract}
USTRALIA made an early start in radio A astronomy at the end of the Second World War, and has remained ever since among the leading countries in this rapidly advancing field. Australian radio astronomers now possess a radio telescope which is the foremost of its type in the world at the present time-a 210-ft. steerable paraboloid, with a surface accuracy of a few millimetres.

The new telescope, which is located at Parkes, New South Wales, 230 miles west of Sydney, was commissioned on October 31 by the Governor-General of the Commonwealth of Australia, His Excellency the Right Hon. Viscount De L'Isle, and it will be operated by the Division of Radiophysics of the Australian Commonwealth Scientific and Industrial Research Organization. The telescope is the first instrument of the Australian National Radio Astronomy Observatory, which was inaugurated at the same time.
\end{abstract}

The plan for a large steerable paraboloid originated seven years ago, when the first specifications were drawn up by Dr. E. G. Bowen, Chief of the Organization's Division of Radiophysies. His vision and enthusiasm have been largely responsible for the successful completion of the project.

A large donation from the Carnegie Corporation (250,000 dollars) enabled the design work to start, and other generous donations were afterwards received from the Rockefeller Foundation (357,000 dollars), and from a number of private donors in Australia. These sums were matched on a pound-for-pound basis by the Australian Commonwealth Government. The total cost of the project has beer about $£ 800,000$

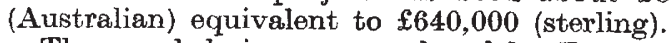

The novel design was produced by Freeman, Fox and Partners, consulting engineers, of London, with Mr. Gilbert Roberts in charge of the responsible group. The construction was carried out by Maschin. enfabrik Augsburg-Nürnberg, A.G., of West Germany, which submitted the best tender, both in price and delivery time, and was awarded the prime contract. The principal sub-contractors were Askania Werke, 